\title{
Water-Clear Cell Adenoma of the Mediastinal Parathyroid Gland
}

\author{
Deniz ARIK' ${ }^{1}$ Emine DÜNDAR ${ }^{1}$, Evrim YILMAZ' ${ }^{\text {, Cumhur SiVRIKOZ }}{ }^{2}$ \\ Department of 'Pathology and ${ }^{2}$ Thorax Surgery, Eskisehir Osmangazi University, Medicine Faculty, ESKIŞEHIR, TURKEY
}

\begin{abstract}
Water-clear cell adenoma of the parathyroid gland is a rare neoplasm that consists of cells with abundant clear-pink cytoplasm. There have only been 19 cases reported in the English literature. Here we report a case of water-clear cell adenoma of the mediastinal parathyroid gland. A 70-year-old male patient presented to the hospital with back pain and a mediastinal mass $6 \mathrm{~cm}$ in size was detected. After excision and microscopic evaluation, uniform, large clear cells with fine cytoplasmic vacuolization, without nuclear atypia, and arranged in solid and acinar patterns were revealed. The cells formed nests that were separated by fine fibrovascular septae and stained positively with anti-parathyroid hormone. To the best of our knowledge, this has not been previously reported in this location. In the differential diagnosis of clear cell lesions of the mediastinum, water-clear cell parathyroid adenoma should be considered.
\end{abstract}

Key Words: Water-clear cell, Adenoma, Ectopic tissue, Mediastinum, Parathyroid gland

\section{INTRODUCTION}

Water-clear cell parathyroid adenoma (WCCA) is very rare. Only nineteen cases have been reported in the English literature (1-17). Water-clear cells (WCCs) are large polygonal cells with a small nucleus and large optically clear cytoplasm. Albright first described these histological features in 1934 (18). WCCs are not seen in normal human parathyroid glands. Their presence has been associated with parathyroid hyperfunction. These cells are considered to represent an end stage of hyperplastic chief cells (19).

In relation to embryological migration patterns, abnormal parathyroid tissues can occur in ectopic locations. Ectopic locations include the superior mediastinum and thymus and areas behind the esophagus or within the thyroid (20).

Here, we present a 70-year-old man with WCCA presenting as a mediastinal mass. To the best of our knowledge, this is the first reported case of WCCA with a mediastinal location. In the differential diagnosis of clear cell lesions of the mediastinum, WCCA should be considered.

\section{CASE REPORT}

A 70-year-old man presented to the hospital with back pain. On computed tomography, a mediastinal mass, $6 \mathrm{~cm}$ in size, was detected between the esophagus and trachea (Figure 1). There were mild osteoporotic changes at the thoracal vertebrae. Positron emission tomographycomputed tomography (PET-CT) revealed that the mass

(Turk Patoloji Derg 2019, 35:157-161)

Received : 08.03.2017 Accepted : 13.06.2017 did not have high glycolytic activity. The serum calcium and parathyroid hormone levels were not evaluated. Surgical excision was planned by the initial diagnosis of a bronchial cyst, pathological lymph node or low-grade malignancy. In open surgery, by intraoperative consultation (frozen section) of the biopsy, a lesion with clear cells was seen, but the biologic behavior of the lesion could not be assessed. The mass was excised, and the operation was finished.

Macroscopically, the specimen measured $6 \times 2.5 \times 2$ $\mathrm{cm}$ in size. It was soft, brown, and almost completely encapsulated. Upon microscopic evaluation, uniform, large clear cells with fine cytoplasmic vacuolization, arranged in solid and acinar patterns, were revealed (Figure 2). There was no lymphatic or vascular invasion, extracapsular extension, pleomorphism, necrosis or mitotic activity. A rim of compressed parathyroid tissue was identified at the periphery of the tumor (Figure 3). In the immunohistochemical evaluation, the tumor cells were positive for cytokeratin (Ventana, AE1/AE3/PCK26, USA), chomogranin (Ventana, LK2H10, USA), synaptophysin (Ventana, SP11, USA) and parathyroid hormone (Ventana, MRQ-31, USA) (Figure 4), but the cells were negative for TTF-1 (Ventana, SP141, USA), and thyroglobulin (Ventana, 2H11+6E1, USA), vimentin (Ventana, v9, USA), CD10 (Ventana, SP67, USA), and the RCC marker (Ventana, PN15, USA). The tumor was diagnosed as "Water-clear cell adenoma of the ectopic parathyroid gland". Two weeks after surgery, the serum parathyroid hormone level was $63.3 \mathrm{pg} /$

Correspondence: Deniz ARIK

Eskisehir Osmangazi University, Medicine Faculty,

Department of Pathology, ESKİ̧EHIR, TURKEY

E-mail: denarik@hotmail.com Phone: +90 22223929 79/4537 
$\mathrm{ml}$ (reference range 15-65) and the calcium level was 9.3 $\mathrm{mg} / \mathrm{dL}$. At 50 months of follow-up, there is no evidence of recurrence.

\section{DISCUSSION}

The adult parathyroid predominantly consists of chief and oxyphilic cells. The water-clear cells are not part of the normal histology of the parathyroid gland. Roth suggested that WCCs are transformed from chief cells, and the presence of these cells is most commonly associated with hyperparathyroidism (19). Miettinen et al. postulated that all types of parathyroid parenchymal cells, including chief cells, oxyphilic cells and WCCs, are variants of a single cell type (21). Chen et al. considered that the occurrence of water-clear cells might represent hyperfunction of the

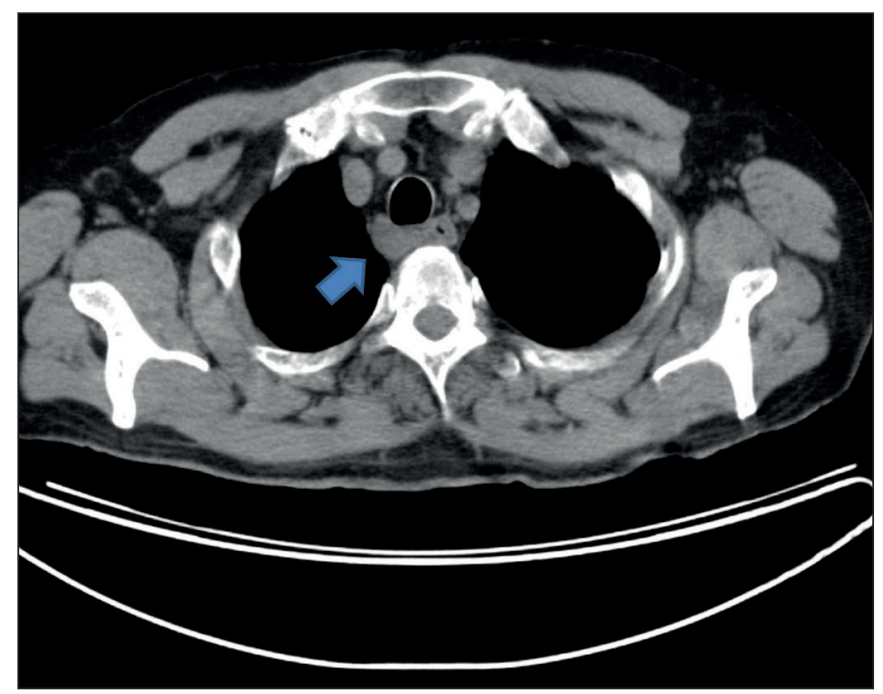

Figure 1: Mass (arrow) between the esophagus and trachea.

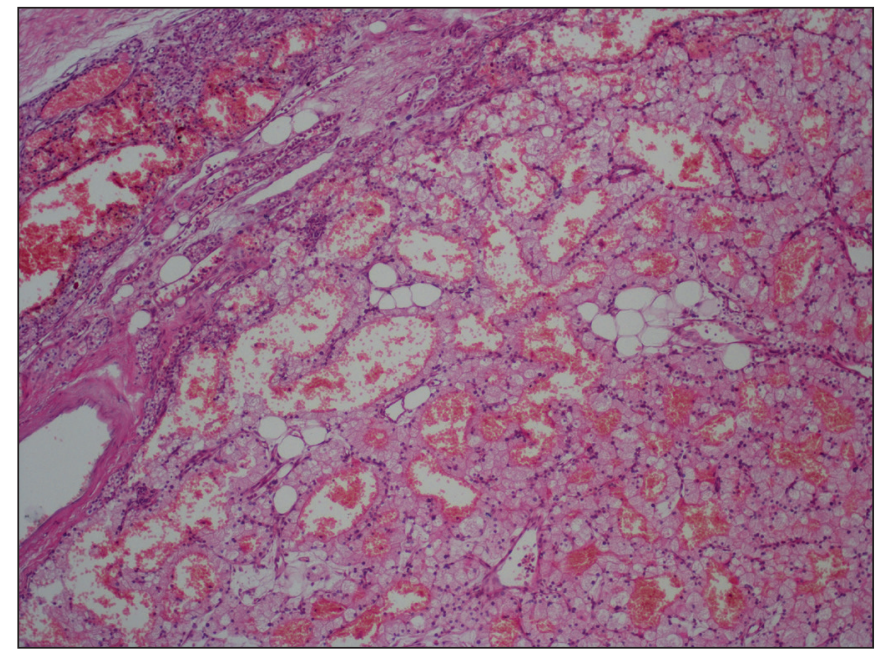

Figure 3: Compressed parathyroid tissue identified at the periphery of the tumor (H\&E; x100). parathyroid glands in SAMP6 (Senescence-accelerated mouse prone 6) mice (22).

Most of the cases of WCCA have presented with hyperparathyroidism. Kanda et al. hypothesized that due to the large size of the adenoma compared with the biochemical and clinical features, WCC adenomas have a "low endocrinological activity" and that the calcium level is not elevated until the adenoma has reached a considerable size (6). In our case, the adenoma was $6 \mathrm{~cm}$ in one dimension, making it one of the largest WCCAs ever presented.

Primary hyperparathyroidism is characterized by the autonomous production of parathyroid hormone, resulting in hypercalcemia. It is most commonly seen with sporadic

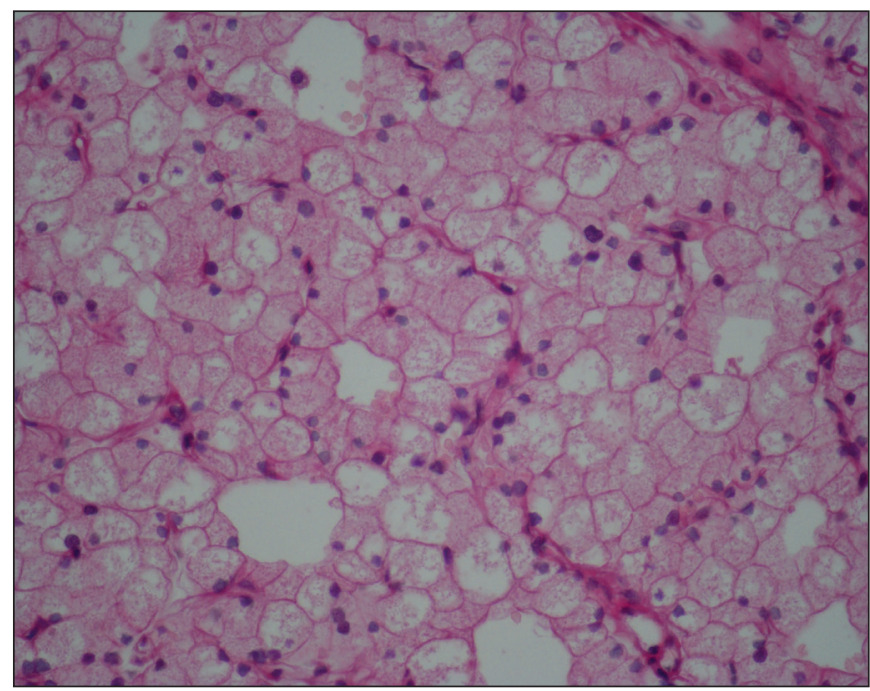

Figure 2: Solid and acinar growth pattern (H\&E; x400).

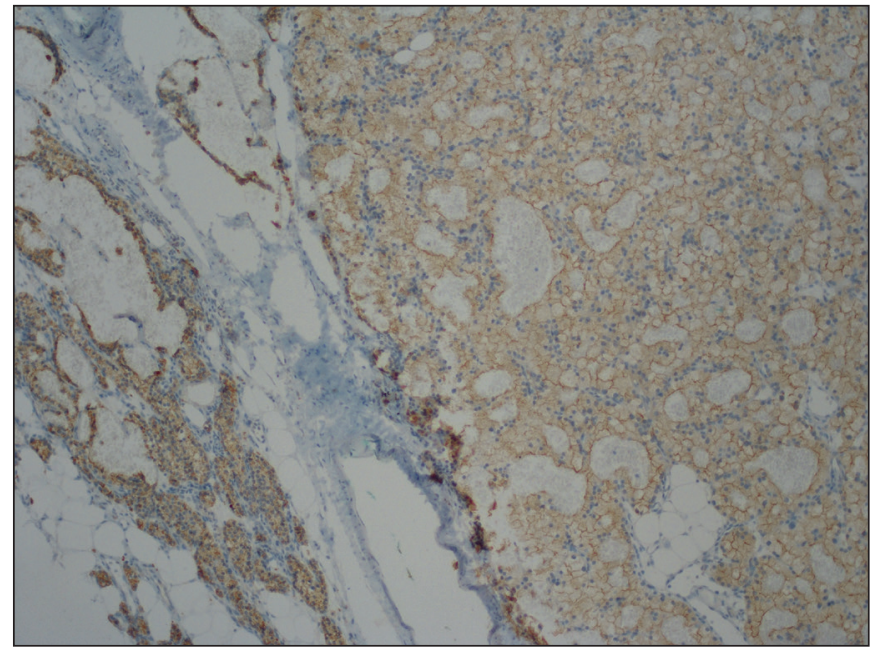

Figure 4: PTH positivity in tumor cells (PTH; x100). 
adenomas, which is followed by hyperplasia, multiple adenomas, and carcinoma. Water-clear cell parathyroid adenoma is extremely rare. There have only been 19 cases reported in the English literature (Table I). In 20 cases (including the present case), the mean age is 57.4 (18-81). In 10 cases, adenomas were seen at the lower left lobe (one of them is a double adenoma). Five were located in the upper right (one of them is a double adenoma) and, 3 were at the upper left lobe. Only three of the 20 adenomas were ectopic. Two of them were intrathyroidal $(4,17)$ and one was mediastinal WCCA (the present case).

The presence of ectopic parathyroid tissue has been attributed to abnormal migration during embryogenesis. The superior parathyroids develop from the fourth pharyngeal pouch, and the inferior parathyroids develop from the third. The inferior parathyroids migrate a greater distance, and they do so in conjunction with thymic tissue. Therefore, these are more likely to be found in ectopic sites (23). Phitayakorn and McHenry reported that $37(16 \%)$ of 231 patients who underwent operations for hyperparathyroidism had ectopic parathyroid glands. Ectopic parathyroid glands were superior in $14(38 \%)$ and inferior in $23(62 \%)$ patients. Superior glands were found in the tracheoesophageal groove in $6(43 \%)$, in the retroesophageal in $3(22 \%)$, in the posterosuperior mediastinum in $2(14 \%)$, in the intrathyroidal area in $1(7 \%)$, within the carotid sheath in $1(7 \%)$, and in the paraesophageal area in $1(7 \%)$ patient. Inferior glands were found in the thymus in $7(30 \%)$, in the anterosuperior mediastinum in $5(22 \%)$, in the intrathyroidal area in $5(22 \%)$, in the thyrothymic ligament in $4(17 \%)$, and undescended in a submandibular location in 2 (9\%) patients (24). Of these locations, our case is consistent with the posterosuperior mediastinal location. Only two of the tumors were ectopic (intrathyroidal) in 19 reported cases of WCCA (4). Our case is the third case located at an ectopic site, and it is unique according to its mediastinal location.

Table I: Summary of reported cases of water-clear cell adenoma of the parathyroid gland

\begin{tabular}{lccccc}
\hline & $\begin{array}{c}\text { Age/ } \\
\text { Gender }\end{array}$ & $\begin{array}{c}\text { Clinical findings or } \\
\text { complaint }\end{array}$ & Localisation & $\begin{array}{c}\text { Tumor } \\
\text { dimension (cm) }\end{array}$ & PTH level \\
\hline Kovacs et al (1) & $48 / \mathrm{m}$ & Nephrolithiasis & Lower left lobe & NA & $4.5 \mathrm{mIU} / \mathrm{ml}$ \\
\hline Grenko et al (2) & $40 / \mathrm{m}$ & Weakness & Upper right lobe & 5 & $945 \mathrm{pg} / \mathrm{dL}$ \\
\hline Begueret et al (3) & $73 / \mathrm{m}$ & Nephrolithiasis & Lower left lobe & 2.8 & $207 \mathrm{pg} / \mathrm{dL}$ \\
\hline Dundar et al (4) & $43 / \mathrm{f}$ & Lethargy & $\begin{array}{c}\text { Intrathyroidal, } \\
\text { upper left lobe }\end{array}$ & 6 & $1667 \mathrm{pg} / \mathrm{dL}$ \\
\hline Kuhel et al (5) & $56 / \mathrm{f}$ & Asymptomatic & $\begin{array}{c}\text { Upper right and lower left } \\
\text { lobe (double adenoma) }\end{array}$ & 2.8 and 1.5 & $52 \mathrm{ng} / \mathrm{L}$ \\
\hline Kanda et al (6) & $52 / \mathrm{f}$ & Nephrolithiasis & Lower left lobe & 6.8 & $672 \mathrm{pg} / \mathrm{dL}$ \\
\hline Prasad et al (7) & $40 / \mathrm{f}$ & Weakness & Upper left lobe & 3 & $346 \mathrm{pg} / \mathrm{dL}$ \\
\hline Kodama et al (8) & $18 / \mathrm{f}$ & Nephrolithiasis & Upper right lobe & 5 & $356 \mathrm{pg} / \mathrm{dL}$ \\
\hline Liang et al (9) & $59 / \mathrm{f}$ & Depression & Upper right lobe & 4.5 & $265 \mathrm{pg} / \mathrm{dL}$ \\
\hline Papanicolau-Sengos & $64 / \mathrm{m}$ & Palpable neck mass & Lower left lobe & 4.7 & $\mathrm{NA}$ \\
\hline et al (10) & $81 / \mathrm{m}$ & Not stated & Upper right lobe & 4 & $22.2 \mathrm{pmol} / \mathrm{L}$ \\
\hline Bai et al (11) & $55 / \mathrm{m}$ & Not stated & Upper left lobe & 1.4 & $15.9 \mathrm{pmol} / \mathrm{L}$ \\
\hline Murakami et al (12) & $59 / \mathrm{f}$ & Nephrolithiasis, bone & Lower left lobe & 0.8 & $72.3 \mathrm{pg} / \mathrm{dL}$ \\
\hline Piggott et al (13) & $74 / \mathrm{f}$ & $\begin{array}{c}\text { Abdominal pain, } \\
\text { constipation and lethargy }\end{array}$ & Lower left lobe & 5.5 & $488.9 \mathrm{ng} / \mathrm{L}$ \\
\hline Ezzat et al (14) & $73 / \mathrm{m}$ & Not stated & Lower left lobe & 3.7 & $30.8 \mathrm{pmol} / \mathrm{L}$ \\
\hline Tassone et al (15) & $74 / \mathrm{f}$ & Not stated & Lower left lobe & $\mathrm{NA}$ & $11.8 \mathrm{pmol} / \mathrm{L}$ \\
\hline Chou et al (16) & $54 / \mathrm{f}$ & Bone pain, depression & Lower left lobe & 2.8 & $130 \mathrm{ng} / \mathrm{L}$ \\
\hline Pirela et al (17) & $34 / \mathrm{f}$ & Acute pancreatitis & Upper left lobe & 3.8 & $450 \mathrm{pg} / \mathrm{dL}$ \\
\hline The present case & $70 / \mathrm{m}$ & Back pain & Mediastinal & 6 & $\mathrm{NA}$ \\
\hline
\end{tabular}

NA: Not available 
Table II: Useful immunohistochemical panel in differential diagnosis of WCCA

\begin{tabular}{|c|c|c|c|c|c|c|c|}
\hline & PTH & TTF-1 & Thyroglobulin & PAX8 & CD117 & GATA3 & S-100 \\
\hline WCCA & + & - & - & + & - & + & - \\
\hline Thyroid tumors & - & + & + & + & - & - & - \\
\hline Lung tumor & - & + & - & - & - & $-1+$ & - \\
\hline Seminoma & - & - & - & + & + & - & - \\
\hline
\end{tabular}

WCCA: Water-clear cell adenoma, PTH: Parathyroid hormone, TTF-1: Thyroid transcription factor-1, PAX8: Paired box 8 (polyclonal antibody), GATA3: GATA binding protein $3,(+)$ : positive, (-): negative.

The differential diagnosis of WCCA includes WCC hyperplasia of the parathyroid, parathyroid chief cell adenoma with focal clear cell change, clear cell changes in a thyroid tumor, clear cell lung tumors, paraganglioma, metastatic renal cell carcinoma, clear cell sarcoma, thymic carcinoma of rare clear cell type, germ cell tumors (seminoma and dysgerminoma) and parathyroid carcinoma. Classic WCC hyperplasia is a diffuse lesion in which all glands are enlarged (20). Foci of WCCs can be seen in chief cell adenoma of the parathyroid, but they are admixed with chief cells (2). Clear cell changes can occur in thyroid neoplasms of various microscopic types, including Hurthle cell tumors, follicular adenomas, papillary carcinomas, and anaplastic carcinomas (25). Paraganglioma may be diagnosed based on the presence of rosettes and Zellballen structures. In metastatic renal cell carcinoma, the useful histologic features in the differential diagnosis with WCCA include multiplicity of the nodules, optically clear cytoplasm, sinusoidal type blood vessels, intraluminal hemorrhage, and high levels of cytoplasmic glycogen and fat (25). In clear cell sarcoma, nuclear pleomorphism and prominent nucleoli may be useful in differential diagnosis. Thymic carcinoma consists of spindle shaped or epithelioid cells. Carcinoma of the thymus with clear cell features is composed of cells with clear cytoplasm and rather bland nuclear features, and shows a lobular or occasionally sheet-like growth pattern (26). Seminoma have polygonal shaped nuclei and thin fibrous bands with lymphocytes. Parathyroid carcinoma is rare but should be included in the differential diagnosis. Water-clear cell carcinoma of the parathyroid gland has also been reported (25). Unequivocal vascular invasion, perineural invasion, gross invasion into adjacent anatomic structures and metastases are features of carcinoma (27). The methylation profile of parathyroid tumors has been shown to distinguish adenoma from carcinoma (28). In the differentiation of parathyroid carcinoma from benign tumors, decreased expression of parafibromin, Bcl-2a, retinoblastoma (Rb), and p27 with PGP9.5 positivity may be helpful (29-31). In addition to being useful, immunohistochemical stains are essential for avoiding a misdiagnosis (Table II).

In conclusion, even though water-clear cell lesions of the parathyroid are rare, they should be considered in the differential diagnosis of clear cell lesions of the neck. Additionally the ectopic location should be considered for mediastinal lesions.

\section{REFERENCES}

1. Kovacs K, Horvath E, Ozawa Y, Yamada S, Matushita H. Large clear cell adenoma of the parathyroid in a patient with MEN1 syndrome. Ultrastructural study of the tumour exhibiting unusual RER formations. Acta Biol Hung. 1994;45:275-84.

2. Grenko RT, Anderson KM, Kauffman G, Abt AB. Waterclear cell adenoma of the parathyroid. A case report with immunohistochemistry and electron microscopy. Arch Pathol Lab Med. 1995;119:1072-4.

3. Begueret H, Belleannée G, Dubrez J, Trouette H, Parrens M, Velly JF, de Mascarel A. Clear cell adenoma of the parathyroid gland: A rare and misleading lesion. Ann Pathol. 1999;19:316-9.

4. Dundar E, Grenko RT, Akalin A, Karahuseyinoglu E, Bildirici K. Intrathyroidal water-clear cell parathyroid adenoma: A case report. Hum Pathol 2001;32:889-92.

5. Kuhel WI, Gonzales D, Hoda SA, Pan L, Chiu A, Giri D, DeLellis RA. Synchronous water-clear cell double parathyroid adenomas a hitherto uncharacterized entity? Arch Pathol Lab Med. 2001;125:256-9.

6. Kanda K, Okada Y, Tanikawa T, Morita E, Tsurudome Y, Konishi T, Tanaka Y. A rare case of primary hyperparathyroidism with clear cell adenoma. Endocr J.2004; 51:207-12.

7. Prasad KK, Agarwal G, Krishnani N. Water-clear cell adenoma of the parathyroid gland: A rare entity. Indian J Pathol Microbiol. 2004;47:39-40.

8. Kodama H, Iihara M, Okamoto T, Obara T. Water-clear cell parathyroid adenoma causing primary hyperparathyroidism in a patient with neurofibromatosis type 1: Report of a case. Surg Today. 2007;37:884-7. 
9. Liang Y, Mojica W, Chen F. Water-clear cell adenoma of parathyroid gland: A case report and literature review. N A J Med Sci. 2010; 3:194-8.

10. Papanicolau-Sengos A, Brumund K, Lin G, Hasteh F. Cytologic findings of a clear cell parathyroid lesion. Diagn Cytopathol. 2013;41:725-8.

11. Bai S, LiVolsi VA, Fraker DL, Bing Z. Water-clear parathyroid adenoma: Report of two cases and literature review. Endocr Pathol. 2012;23:196-200.

12. Murakami K, Watanabe M, Nakashima N, Fujimori K, Ishida K, Ohuchi N, Sasano H. Water-clear cell adenoma associated with primary hyperparathyroidism: Report of a case. Surg Today. 2014;44:773-7.

13. Piggott RP, Waters PS, Ashraf J, Colesky F, Kerin MJ. Water-clear cell adenoma: A rare form of hyperparathyroidism. Int J Surg Case Rep. 2013;4:911-3.

14. Ezzat T, Maclean GM, Parameswaran R, Phillips B, Komar V, Mihai R, Sadler G, Courtney S. Primary hyperparathyroidism with water clear cell content: The impact of histological diagnosis on clinical management and outcome. Ann R Coll Surg Engl. 2013;95:60-2.

15. Tassone P, Kaplan S, Kenyon L, David R, Pribitkin E. Water clear cell parathyroid adenoma: Case report and literature review. Thyroid Disorders Ther. 2014;3:160.

16. Chou YH, Jhuang JY, Hsieh MS. Water-clear cell parathyroid adenoma in a patient with acute pancreatitis. J Formos Med Assoc. 2014;113:872-3.

17. Pirela D, Treitl D, El Hussein S, Poppiti R, Mesko T, Manzano A. Intrathyroidal clear cell tumor of parathyroid origin with review of literature. Case Rep Pathol. 2016;2016:7169564.

18. Albright F, Bloomberg E, Castleman B, Churchill ED. Hyperparathyroidism due to diffuse hyperplasia of all parathyroid glands rather than adenoma of one: Clinical studies on three such cases. Arch Intern Med. 1934;54:315-29.

19. Roth SI. The ultrastructure of primary water-clear cell hyperplasia of the parathyroid glands. Am J Pathol. 1970;61:233-48.
20. LiVolsi VA, Hamilton R. Intraoperative assessment of parathyroid gland pathology. A common view from surgeon and the pathologist. Am J Clin Pathol. 1994;102:365-73.

21. Miettinen M, Clark R, Lehto VP, Virtanen I, Damjanov I. Intermediate-filament proteins in parathyroid glands and parathyroid adenomas. Arch Pathol Lab Med. 1985;109:986-9.

22. Chen H, Emura S, Shoumura S. Ultrastructure of the waterclear cell in the parathyroid gland of SAMP6 mice. Tissue Cell. 2006;38: 187-92.

23. Carlson D. Parathyroid pathology: Hyperparathyroidism and parathyroid tumors. Arch Pathol Lab Med. 2010;134:1639-44.

24. Phitayakorn R, McHenry CR. Incidence and location of ectopic abnormal parathyroid glands. Am J Surg. 2006;191;418-23.

25. Carcangiu ML, Sibley RK, Rosai J. Clear cell change in primary thyroid tumors. A study of 35 cases. Am j Surg Pathol. 1985;9:70522.

26. Hasserjian RP, Klimstra DS, Rosai J. Carcinoma of the thymus with clear-cell features. Report of eight cases and review of the literature. Am J Surg Pathol. 1995;19:835-41.

27. Duan K, Mete Ö. Parathyroid carcinoma: Diagnosis and clinical implications. Turk Patoloji Derg. 2015;31 Suppl 1:80-97.

28. Starker LF, Svedlund J, Udelsman R, Dralle H, Akerström G, Westin G, Lifton RP, Björklund P, Carling T. The DNA methylome of benign and malignant parathyroid tumors. Genes Chromosomes Cancer. 2011;50:735-45.

29. Kruijff S, Sidhu SB, Sywak MS, Gill AJ, Delbridge LW. Negative parafibromin staining predicts malignant behavior in atypical parathyroid adenomas. Ann Surg Oncol. 2014;21:426-33.

30. Howell VM, Gill A, Clarkson A, Nelson AE, Dunne R, Delbridge LW, Robinson BG, Teh BT, Gimm O, Marsh DJ. Accuracy of combined protein gene product 9.5 and parafibromin markers for immunohistochemical diagnosis of parathyroid carcinoma. J Clin Endocrinol Metab. 2009;94:434-41.

31. Erovic BM, Harris L, Jamali M, Goldstein DP, Irish JC, Asa SL, Mete O. Biomarkers of parathyroid carcinoma. Endocr Pathol. 2012;23:221-231. 